\title{
Reasons for Reading in Infancy and the Child's Development under the Light of Historical-Cultural Theory: A Path to Understand the Development of the Reading Ability in Childhood
}

\author{
Cyntia G. G. Simões Girotto1, Sandra Aparecida Pires Franco², Cassiana Magalhães², \\ Greice Ferreira da Silva², Ana Claudia Bazé de Lima3 ${ }^{3}$ Daniele Aparecida Russo", \\ Andressa Cristina Molinari ${ }^{5}$
}

\footnotetext{
${ }^{1}$ Department of Didactics, São Paulo State University, São Paulo, Brazil

${ }^{2}$ Department of Education, Londrina State University, Londrina, Brazil

${ }^{3}$ Secretary of Culture and Education, TrêsLagoas, Mato Grosso do Sul, Brazil

${ }^{4}$ São Paulo State University, São Paulo, Brazil

${ }^{5}$ Department of Foreign Language Teaching, Londrina State University, Londrina, Brazil

Email: cyntia@marilia.unesp.br
}

How to cite this paper: Girotto, C. G. G. S., Franco, S. A. P., Magalhães, C., da Silva, G. F., de Lima, A. C. B., Russo, D. A., \& Molinari, A. C. (2017). Reasons for Reading in Infancy and the Child's Development under the Light of Historical-Cultural Theory: A Path to Understand the Development of the Reading Ability in Childhood. Creative Education, 8, 993-1000. https://doi.org/10.4236/ce.2017.86072

Received: March 28, 2017

Accepted: May 28, 2017

Published: May 31, 2017

Copyright $\odot 2017$ by authors and Scientific Research Publishing Inc. This work is licensed under the Creative Commons Attribution International License (CC BY 4.0).

http://creativecommons.org/licenses/by/4.0/

\begin{abstract}
This essay is a bibliographical-theoretical research that focuses on understanding the reasons and the conditions necessary for the development of the reading ability since infancy and its relation to the child's development. Thus, it aims at comprehending the process of literacy learning in teaching and in learning the ability to read since infancy. The objectives and methodology meant to understand the relationship between written language, reading and the development of early readers in their relation to the book. For achieving that, we considered the concept of what a child is, of a child's development, of the reading ability, and the formation of the early reader as the basis for the discussion, under Historical-Cultural Theory. The results show that when a child is treated as an individual who is beyond classification and categorization-which establishes a child's development as a linear process defined by nature-to view her as an individual that constructs thoughts, language, imagination, and affect, thus constructing the self, in its life history and in the relations with the other.
\end{abstract}

\section{Keywords}

Literacy, Education, Mediation, Reading 


\section{First Words}

In this essay we reflect upon the Historical-Cultural Theory, which allows us to understand not the first (biological), but the second nature, the social. In this sense, the theory supports our reflections about how the reading ability takes place in connection with the child's development. The goal is to explain the child's development dynamics, in her intelligence as well as in personality.

The epigraph above explains the revolutionary process of qualitative transformations that takes place in different ages. The metaphor by the acclaimed Byelorussian researcher (Vygotsky, 1996) calls attention to the different stages the child's brain architecture develops into and to the periods of transition in which culturally constructed bases expose the apparent "extinction" of some processes and the "beginning" of others. Some activities in processes of developing and learning do not cease to exist; they become latent, as bases for the growth of new mental stages that become secondary in face of new stages that rise.

While the caterpillar does its tasks almost day and night, moving slowly over branches and leaves, eating uninterruptedly, it seems to fall asleep as it becomes chrysalis. The transition into another position in the world, resulting from its new stage and nature, indicates unanticipated appropriations: from a crawling being to a winged one-the rupture from former appearances announces itself. However, in the dormant stage of the chrysalis there is a latent revolution, not a mere disappearing but an astounding "transformation", a "new way of acting", that increase the possibilities of living for the new being, whose features outdistance the former creature and raise the caterpillar-chrysalis into a butterfly.

This way, the revolutionary process of the child's psyche, depending on life conditions and education, follows a similar path. In order to understand it, we rely also on some of Vygotsky's followers, who discuss the process mentioned above, and help us build on the investigation on it so that we can connect it to the construction of the bases for the literacy attitude in infancy. Leontiev (1978), Bozhóvich (1987), Elkonin (1987, 1998), and Mukhina (1995) make crucial claims for our understanding of the transformations of a child's mental activities and their direct effects on her development and formation.

This is a bibliographical-theoretical research, whose main objective is to understand the reasons and conditions for the development of reading since infancy and its relation with childhood development, which includes the comprehension of Literacy education process and the teaching-learning process. The objectives, articulated with the methodology, were based on the understanding of the relations between written language, literary reading and the formation of the reading process in infancy. For this reason, we mention in this article what we understand by child, child's development, a reading class in childhood, the reader's formation based on the principles of Historical-Cultural Theory.

In this discussion, we search for the premises for the reading activity, for the perception, gestures and actions of reading, imbricated in the successive process of appropriating the reading act; in the conquest of the ability and attitude of/for 
reading in infancy.

\section{Childhood Development in Historical-Cultural Theory}

According to Leontiev (1978), childhood is the "spontaneous" period of intelligence and personality development. It means that during the first years of life there is not a self-consciousness in relation to the formation of this system. According to the researcher, it is a moment of preparation, which, in adolescence, in satisfactory life conditions and education, culminates in the birth of an intelligence and personality conscious of itself-a crucial tenet for the comprehension of the reading identity constructed during childhood.

Vygotsky's disciple argues that there are two bases for the psyche development. The first is composed by the abundance of ties the individual has with the world through activities. The second one, directly related to the first, é constituted by the hierarchization and subordination of motives to the mentioned activities.

The complementarity relationship between the two bases requires that the individual progressively becomes conscious of the fundamental motive of her/his life, of the vital objective, through a complex movement that allows the individual to analyze her innermost being through the system of assimilated meanings and concepts. It is this movement that stimulates the development of the individuality for-itself, of a conscious and self-conscious personality that regulates its own personal behavior, based on the knowledge of its own motives and on its relationship with the interests of the group the individual lives and with the humankind as a whole.

Leontiev shows evidence that the non-hierarchization of motives makes the individual's life fragmented and dependent on external motivations, which do not aggregate humanizing meanings to her existence and do not contribute to her unification as a singular, universal, and free being. At this level, the fusion between man and the humankind, which, in Gorki's words (apud Leontiev, 1978: 172), represents the conversion of man into "man of humankind", does not take place. From that it is possible to understand the fusion of the child with literacy, and the conversion of the child in 'a child reader of literature', in literatize $^{1}$, or literatizing herself ${ }^{2}$.

This way, how can we conceive on the vital motive that makes a child to live the literacy world? (Girotto, 2010, 2012, 2016), considering that it is this movement that makes possible the development of "reading in itself" into "reading for itself", in a conscious and self-conscious attitude that regulates the reading beha-

\footnotetext{
${ }^{1}$ There is a set of neologisms, such as literatizar, literar, leiturizando, leiturizar-se (no direct translations from Portuguese), that can represent the process of literacy learning, the route to take possession of cultural assets specific from literature. Relationships between the various activities performed by small and "not so small" children can generate.

${ }^{2}$ The tern "literatization" (from Portuguese leiturização) was coined by Jean Foucambert when he was doing research for the INRP Institute of Pedagogical Research In France (currently IFÉ). He focused on the process of literacy, which, most often, makes the child face the oral transcripts of his-her writings, and almost never, approaches the actual functioning of writing, thus, reducing the possibilities of making the student a reader.
} 
vior.

The school routine, that supposedly favors literacy learning, is fractured and submissive, mostly to external motivations; it does not aggregate humanizing senses to children in developing literacy learning, and does not add to their unification as singular, universal, and free beings in the matter of becoming literate in literacy narratives.

If the development of intelligence and personality is connected to a hierarchy of motives and to the individual's subordination to them, we believe that the bases for the formation of a literate identity is linked to the hierarchy of reading motives the child has, in subordination to the child's initial actions and gestures regarding the ability to read this set of reasons to have a literary perspective.

Furthermore, if during childhood the motives are horizontally related, it is possible to say that the fundamental role of education is to create humanizing needs and enrich the set of motives of the child's behavior. That is to say that the first role of education is the creation of needs for reading, enhancing the motives that provoke the reading attitude in childhood.

The relationships between the various activities performed by small and 'not so small' children can generate a movement of greater complexity of the motivational sphere, and, consequently, so does the potentiality of the teacher's role as a mediator of literacy, as a trigger for new humanizing needs for the act of reading, in search of adequate ways for achieving-along with the children-high levels of human consciousness (Fernandes \& Franco, 2016).

The enhancement of actions gives opportunity for changing the objectives in motives for new activities, which, in a continuum, helps in the development of consciousness about the motives of the personality and self-consciousness. In this way, in adolescence, the motives relate vertically to each other, progressively forming a "harmonic system of personal senses" (Leontiev, 1978: 165), an event that modifies the course of the psychic development, and that configures, eventually, an evolved personality.

We suggest that the ability and the attitude to read can develop by taking into consideration the whole system of personal meanings, by promoting ways for the development of a literacy identity. As a human quality, the ability to read can only be appropriated by children if the written language functions according to the reasons it was created for by man. The enhancement of each child s action, in direct and mediated access to books and to literary art can help, so that experiences encourage a lasting, tangible purpose of the books 'usefulness', and of reading as a cultural practice, historically and socially constructed.

For Historic-Cultural Theory, childhood determines a fundamental moment of the intelligence and personality development, as it is when important psyche changes-related to the positioning of the self in face of the world and to the hierarchization of motives and activities' subordination to them-consolidate. Leontiev claims that

Each one of these periods, that have fundamental meaning in the development of the child's personality, has its own characteristics. The adolescence period 
distinguishes itself by the beginning of the subject's active work on herself; it is the time of the formation of the moral consciousness, of ideals, of the self-consciousness development. The period of pre-school childhood is the initial development of the personality, the time of developing personal "mechanisms" of behavior. In pre-school years the first knots in the child s development are tied, the first bonds and relations that constitute the new superior unity of the activity, and simultaneously, the superior unity of the subject, are established: the personality unity, the person's identity [emphasis added]. Pre-school childhood is so important because it is the period of the factual formation of the personality's psychological mechanisms (Leontiev, 1987: 58).

In this perspective, childhood literacy becomes vital in the formation of the prospective, autonomous reader. The I-reader's consciousness, product of this process, depends fundamentally on the knowledge and representations of oneself as a reader and on the purposes that reading has for the child, even if unconsciously. For this reason, it is a matter of paramount importance to provide educational conditions permeated by positive and affective literacy experiences that respect and value the child reader and her conquests - at any time of her development, through horizontal relations-and subsequently, to see her as a reader subject. And what does it mean to be subject in/ of reading? What does it mean to be a reader subject of children's literature?

If in the period between the first months to the age of six years the foundations for the child's evolution of personality and intelligence are established, so are the bases for the development of her reading identity. At first, incipiently, and then in more sophisticated ways, the child becomes able to subordinate reasons for the act of reading, to produce acts and gestures of reading whose objectives answer only-in this time of life-indirectly to the reasons for her reading activity. The unambiguous clarity of these processes guides the teacher in her mediation of reading practices, in their planning, implementation and assessment.

Although the child is not aware of the development of her personality and intelligence, it is significant for her becoming conscious of herself and of the world. At first, in her relation to the book and to literature, there is no perception of herself and the reading ability; she deals with the book in a disorderly way; mimes the adult in reading, or plays with the book. Later, the small learner will be conscious of her reader condition and of the written culture, of the reading world, of the literature universe, and her autonomy in reading, and these will result in the conquest of a fully developed reading identity.

An organized, planned, and systemic literacy learning should take into consideration activities that create bonds between children, individually and collectively, with an experienced reader through the book and its uses. It should also consider the particular bond that each child creates with 'literary stuff through the mediator's actions.

It is necessary to ask: what does it mean to say that a child must be treated as a subject-as we usually see in scientific research, in academic and informal debates? Is she a subject of rights, of her learning, of her development? We should 
think about the space-time that the category subjectivity/individuality has in the debates on childhood. It is necessary to ask about the meanings inherent to the categorization of a child's subjectivity during our times, informing the position claimed in this essay. After all, how can we figure babies who can read? How to accept that, since infancy, children are learning and developing their ability to read when they have mediated access to books, to reading practices and storytelling? How can we defend the argument of learning to read by reading' since infancy without implying that it is a defense of early schooling in children's education?

We must point out that it seems that the pedagogical thought does not acknowledge nor gives space to the category subjectivity/individuality. Taking into account the Cartesian model, which has been the most common way of thinking man, society, the world, the sciences, the child, and "everything else", pedagogy has used universalizing and classifying patterns, and has not opened a space-time for comprehending humankind, and as consequence, for the child reader learner as a singular, concrete being. In this sense, subjectivity has been considered a non-scientific category, especially when babies and small children are the focus.

In this essay, the concepts of individuality and subjectivity are approached as related, so that we can understand the bases of the development of the reading identity. Based on the insights of the Russian theoreticians, we defend the principle that human consciousness is constituted by reality's subjective reflections; that it defines the individual as a unique, unrepeatable being in her cognitive-affective relationship to the world, to which the personality's and intelligence's interfunctional systems adjust themselves. The individual's personality is considered as a functional system that psychologically expresses human subjectivity/individuality.

The paradox consists in simultaneously minimizing subjectivity because of man's psychological categorization-considered under an empiric and naturalizing perspective-and in raising the child to the condition of a subject (Raizer, 2007; Magalhães, 2014). By choosing to view her as a subject we must reflect on this condition in a unique way. By being a subject, the child learner of reading is someone that-through socio-historical discursive relations-appropriates the reading world, developing a special way of acting on it and forming her personality and intelligence (Silva, 2009, 2013).

In the perspective discussed here, as we take the subjectivity into consideration in the matter of "literatize", we are able to identify the child as someone who is in a reading activity, moved by personal reasons for doing that task, with motives of/for reading constructed by the appropriation of the world of the written culture, in dialogical relations as well as by ascribing meanings-that express one's ways of experiencing them-to the literary-esthetic sphere. It values the subject as a sign of the presence of every human being in the world. It elevates the childhood specificities, and at the same time, singles out each child as a reader in formation, present in the reading world, in a literary circle, con- 
stituting it and constituting herself.

\section{Final Words}

In summary, through a bibliographical-theoretical research, whose main objective was to understand the motives and conditions for reading from an early age and its relationship with child development, which includes understanding the process of Literary Education in Their actions to teach and to learn the capacity and attitude to read since the Early Childhood Education, we could the child beyond a normalizing and categorizing pattern, which defines his-her development as a linear process previously established by nature. Instead, we were able to perceive the child as an individual who constructs his-her thoughts, language, imagination, affects, and herself, in her life story and in the relationships, he-she establishes with others.

Thus, reaching the objectives listed in the previous pages, we can conceive the child as subject, capable of overcoming a classificatory and normalizing understanding, which sees development as a linear process previously established by nature, to perceive it as someone who constructs its thoughts, its language, its imagination, its affections and in the end, constructs itself the relationships established with others. It is also possible to perceive that the child's development is conditioned by its integration in social relations, by the experiences that make possible the process of humanization, so to speak, the reading process as well.

It seems clear that in regard to the acquisition of the reading ability, it is mandatory to face the need for achieving new procedures, ways, and actions in dealing with written material, especially books, as without them, it will be impossible for the child to accomplish the adult reading activity, as an experienced reader does. Considering that the Historical-Cultural Theory considers the human development in a systemic and interfunctional way, all activities are important for the formation of new psychic abilities and of new cognitive-affective reflexes about reality.

Finally, the understanding of infancy, child's development, the act of reading in childhood, are relevant for future researches since human development is understood in a systemic and cross-functional way by the Historical-Cultural Theory. In this theoretical perspective, all activities are important for the formation of new psychic capacities, new reflexes, cognitive and affective, about reality. They also have in mind the appropriation of the reader's capacity and attitude to allow the child, in the movement of his-her development, the opportunity to subordinate his-her actions and embryonic gestures of reading among themselves and to establish the motives of their mental strategies and actions to read those who qualify as sense generators and who make up the individual's unique way of relating to himself, to the people and to the world around him through literary activity.

\section{References}

Bozhóvich, L. (1987). Las Etapas de Formácion de la Personalidadenla Ontogenesis. In V. 
Davidov, \& M. Shuare (Eds.), La Psicologia Evolutiva y Pedagógicaenel URSS: Antologia. Moscou: Editorial Progresso.

Elkonin, D. (1987). Sobre el Problema de la Periodizacióndel Desarrollo psíquico em lainfancya. In V. Davidov, \& M. Shuare (Eds.), La Psicologia Evolutiva $y$ Pedagógicaenel URSS: Antologia (pp. 125-142). Moscou: Editorial Progresso.

Elkonin, D. (1998). Psicologia do Jogo. São Paulo: Martins Fontes.

Fernandes, G. F. G., \& Franco, S. A. P. (2016). A Apropriação do Conhecimento como Elemento de Transformação do Trabalho Educativo. Revista Ibero-Americana de Estudosem Educação, 11, 2191-2204. https://doi.org/10.21723/riaee.v11.n4.8752

Girotto, C. G. G. S. (2012). Educação Literária e Formação de Leitores: Da Leitura em Si para a Leitura para Si. Ensinoem Re-Vista, 19, 167-179.

Girotto, C. G. G. S. (2016) A Criança, o Livro e a Literatura: A Identidade Leitora em Constituição na Infância. Full Professor Thesis. Marilia: Universidade Estadual Paulista, Faculdade de Filosofia e Ciências.

Girotto, C. G. G. S., \& Souza, R. J. (2010). Estratégia de Leitura: Para Ensinar Alunos a Compreender o Que Leem. In R. J. Souza, C. G. G. S. Girotto, \& D. B. Arena (Eds.), Ler e Compreender: Estratégias de Leitura. Campinas: Mercado das Letras.

Leontiev, A. N. (1978). Uma Contribuição à Teoria do Desenvolvimento da Psique Infantil. Actividad, Consciência e Personalidad. Buenos Aires: Ciências del Hombre.

Magalhães, C. (2014). Implicações da Teoria Histórico-Cultural no Processo de Formação de Professores da Educação Infantil. Ph.D. Thesis, Marilia: Universidade Estadual de Marilia.

Mukhina, V. (1995). Psicologia da Idade Pré-Escolar: Um Manual Completo para Compreender e Ensinar a Criança desde o Nascimento até os Sete Anos. Cláudia Berliner Trans., São Paulo: Martins Fontes.

Raizer, C. M (2007). Portfólio na Educação Infantil: Desvelando Possibilidades para a Avaliação Formativa. Londrina: Universidade Estadual de Londrina.

Silva, G. F. (2009). Formação de Leitores na Educação Infantil: Contribuições das Histórias em Quadrinhos. Marilia: Universidade Estadual Paulista.

Silva, G. F. (2013). O Leitor e o Recriador de Gêneros Discursivos na Educação Infantil. PhD Thesis, Marilia: Universidade Estadual Paulista.

Vygotsky, L. S. (1996). Obras Escogidas. Tomo IV. Madri: Visor. 
Submit or recommend next manuscript to SCIRP and we will provide best service for you:

Accepting pre-submission inquiries through Email, Facebook, LinkedIn, Twitter, etc. A wide selection of journals (inclusive of 9 subjects, more than 200 journals)

Providing 24-hour high-quality service

User-friendly online submission system

Fair and swift peer-review system

Efficient typesetting and proofreading procedure

Display of the result of downloads and visits, as well as the number of cited articles Maximum dissemination of your research work

Submit your manuscript at: http://papersubmission.scirp.org/

Or contact ce@scirp.org 